Counsellia: Jurnal Bimbingan dan Konseling, 10 (2), $2020 \mid 176-189$

Copyright $(2020$ Universitas PGRI Madiun

ISSN: 2088-3072 (Print) / 2477-5886 (Online)

Available online at: http://e-journal.unipma.ac.id/index.php/JBK

DOI: 10.25273/counsellia.v10i2.7768.

\title{
Teacher professional quality: Counselling services with technology in Pandemic Covid-19
}

\author{
Agus Supriyanto ${ }^{1}$, Sri Hartini ${ }^{2}$, Wahyu Nila Irdasari ${ }^{3}$, Aulia Miftahul ${ }^{4}$, Siska \\ Oktapiana $^{5}$, Sesya Dias Mumpuni ${ }^{6}$ \\ ${ }^{1}$ Faculty of Teacher Training and Education, Universitas Ahmad Dahlan, Yogyakarta \\ agus.supriyanto@bk.uad.ac.id \\ ${ }^{2}$ Faculty of Teacher Training and Education, Universitas Ahmad Dahlan, Yogyakarta \\ sri.hartini@bk.uad.ac.id \\ ${ }^{3}$ Faculty of Teacher Training and Education, Universitas Ahmad Dahlan, Yogyakarta \\ wahyu1900001029@webmail.uad.ac.id \\ ${ }^{4}$ Faculty of Teacher Training and Education, Universitas Ahmad Dahlan, Yogyakarta \\ aulia1900001037@webmail.uad.ac.id \\ ${ }^{5}$ Faculty of Teacher Training and Education, Universitas Ahmad Dahlan, Yogyakarta \\ siska190001007@webmail.uad.ac.id \\ ${ }^{6}$ Study Program of Guidance and Counselling, Pancasakti University, Tegal. \\ dias.mumpuni@live.com
}

\begin{abstract}
The Covid-19 pandemic is affecting academic processes around the world and the emergence of problems in students. School counsellors have a significant role in helping problems and developing student potential through counselling services with digital technology media. This study focuses on discovering various technologies that were applied and used by school counsellors in the process of counselling services during the Covid-19 pandemic. The research method used a case study method, and a qualitative descriptive method with totally subject 20 teacher professional education alumni worked as school counsellors in various islands in Indonesia. The research instrument used an open questionnaire with distribution through google form media and descriptive qualitative data analysis. The results of the study found that asynchronous media and technology-based synchronous media were the leading alternatives for online counselling services during the Covid-19 epidemic. The use of asynchronous media with WhatsApp, Facebook, Instagram or social media, as well as synchronous media with Zoom, Webex, Google Meeting, or Hangout, can help solve problems and develop student potential. Recommendations for school counsellors to immediately adapt to the era of disruption and technology in counselling services. The following advice for the government is the administration of teacher and student welfare.
\end{abstract}

Keywords: School Counsellors, Media, Technology, Counselling.

\section{INTRODUCTION}

The Covid-19 virus pandemic represents a comprehensive global health crisis (Cucinotta \& Vanelli, 2020; Djalante et al., 2020; Van Bavel et al., 2020), one of which is the world crisis of education. Covid-19 pandemic is a severe problem for the world of education in Indonesia and internationally. The spread of the coronavirus grew very fast from March to September 2020. The number of patients infected with Covid-19 has 
increased and has an impact on the process of providing education. The Indonesian government implements a lockdown system in various regions. The government lockdown applied by educational institutions, including schools and universities.

Lockdown or regional quarantine is implemented in the world of education to reduce and reduce the coronavirus epidemic (Abdullah, 2020; Setiati \& Azwar, 2020), especially in future generations of students. The policy change from a lockdown system has increased to large-scale social restrictions to prevent the transmission of the Covid-19 virus (Yanti et al., 2020). The application of social distancing does indeed protect students, lecturers, teachers, and staff, to ensure the continuity of education (Iyer et al., 2020). The Work From Home (WFH) implementation to reduce the spread of Covid-19 in the world of education.

The reality is that lockdown and WFH in education have a significant and negative impact on the learning process (Burgess \& Sievertsen, 2020). The emergence of learning disorders in the learning process due to the absence of school activities and has an impact on vulnerable groups, namely young students, social disadvantages, special needs in learning, or the context of family work for the supervision of children learning at home (Brown et al., 2020). The fact is that the learning process isn't optimal at home. In China, difficulties arise in the learning process due to weaknesses in online learning infrastructure, the inexperience of teachers, information gaps, complex environments at home, and unequal learning outcomes (Zhang et al., 2020). Meanwhile, in Indonesia, teachers and students have obstacles to the use of e-learning (Almanthari et al., 2020). Barriers to using e-learning have an impact on psychological disorders with excess anxiety. Teachers also have problems related to work motivation due to the emergence of the burden of paying for electricity, internet costs, and excessive data security problems due to WFH (Purwanto et al., 2020).

Students need guidance and counselling services with the use of technology during the Covid-19 pandemic. Online collaboration and technological readiness have an impact on the success of students (Aliyyah et al., 2020). Guidance and counselling services are urgently needed because students at the elementary, middle school and college students experience various problems. The variety of issues experienced by students are mental health problems, misinformation problems, educational problems, and coping strategy problems (Pragholapati, 2020). These various problems require counselling services from school counsellors.

Counsellors can provide individual counselling during the Covid-19 pandemic. Individual counselling as assistance school counsellors can provide personal counselling service during the Covid-19 epidemic. They were counselling as assistance by experts to individuals who need to solve environmental problems. School counsellors as practitioners for helping a student. School counsellor improving the psychological state of students and parents in alleviating high levels of stress, anxiety, depression, and other psychological conditions through online counselling, distribution of disease prevention brochures, websites, YouTube tutorial videos, videos, short films, online discussions through WhatsApp groups, and other means (Ifdil et al., 2020). Consultation videos can also apply electronically to alleviate student problems during the Covid-19 pandemic (Greenhalgh et al., 2020). Counselling services using digital media to respond to global challenges to issues that have arisen during the Covid-19 epidemic Covid-19 (Vostanis \& Bell, 2020).

Guidance and counselling services during the Covid-19 pandemic are beneficial for students who experience a problem. Assistance and counselling services are said to be useful in solving problems if they are directly related to students. Individual counselling aims to change personal behaviour in dealing with issues related to the environment and 
everyday life, especially issues that arise during the Covid-19 pandemic for the desired purpose. This study was to discover various technologies used by school counsellors in the process of individual counselling services during the Covid-19 epidemic.

\section{RESEARCH METHOD}

\section{Model of Research}

This research uses a qualitative approach. The case study method and the qualitative descriptive method combination used in this research. A qualitative descriptive method to reveal the various media used by school counsellors in the implementation of online individual counselling services. Meanwhile, case studies are to tell multiple obstacles and problems in the performance of online personal counselling services. The results of the survey to reveal the media of online individual counselling services along with the issues and obstacles of the online counselling service process. The findings of the research are to find solutions in implementing personal online counselling services.

\section{Research Subject}

The research subjects were school counsellors/guidance and counselling teachers from graduated from the Professional Teacher Education Program at Ahmad Dahlan University. The total of research subjects amounted to 20 alumni research instrument with an open questionnaire. Questionnaires were distributed to school counsellors to find out the media used in individual counselling services, the application of individual counselling with online media, problems with online counselling, and obstacles to online counselling. Research time at the end of the 2019/2020 school year as an evaluation of the counselling program.

Table 1. Research Subjects (School Counselors in Various Areas in Indonesia)

\begin{tabular}{|c|c|c|c|c|c|}
\hline No & $\begin{array}{l}\text { Initial } \\
\text { Name }\end{array}$ & Working Area & No & $\begin{array}{l}\text { Initial } \\
\text { Name }\end{array}$ & Working Area \\
\hline 1 & $\mathrm{AR}$ & Tabalong, South Kalimantan & 11 & GU & West Kutai, East Kalimantan \\
\hline 2 & SA & Konawe, Southeast Sulawesi & 12 & $\mathrm{JU}$ & Pasar Utara, East Kalimantan \\
\hline 3 & HA & Kurau, South Kalimantan & 13 & RY & West Kutai, East Kalimantan \\
\hline 4 & $\mathrm{AC}$ & Purbalingga, Central Java & 14 & MR & South Bontang, East Kalimantan \\
\hline 5 & IS & Tapin, South Kalimantan & 15 & SU & East Kutai, East Kalimantan \\
\hline 6 & II & Tuban, East Java & 16 & YS & Tabalong, South Kalimantan \\
\hline 7 & $\mathrm{NH}$ & $\begin{array}{l}\text { Sleman, Yogyakarta Special } \\
\text { Region }\end{array}$ & 17 & SY & $\begin{array}{ll}\text { Bangka } & \text { Tengah, } \\
\text { Belitung } & \end{array}$ \\
\hline 8 & NT & Tabalong, South Kalimantan & 18 & PA & Ponorogo, East Java \\
\hline 9 & $\mathrm{ZA}$ & $\begin{array}{l}\text { West Bangka, Bangka } \\
\text { Belitung Islands }\end{array}$ & 19 & $\mathrm{BA}$ & Balangan, South Kalimantan \\
\hline 10 & RU & East Kutai, East Kalimantan & 20 & IU & Malang, East Java \\
\hline
\end{tabular}

\section{Research Instrument, Research Procedures and Data Analysis}

The research instrument used an open questionnaire with distribution through google form media. The research results will be analyzed qualitatively based on the context of the findings from each aspect of the study. Discussion of research results is at four elements 1) online counselling media, 2) application of online counselling media, 3) online counselling problems, and 4) obstacles to online counselling. Four analysis results to find solutions to the application of online counselling for school counsellors during the Covid-19 epidemic. The analysis used three stages in the form of data reduction, data presentation, and data conclusion. The results of the data conclusions next discuss. 


\section{RESULTS AND DISCUSSION}

\section{Result}

The results of the study found a variety of media used by school counsellors in the implementation of counselling services. The extension media adjusted to the conditions of students during the Covid-19 pandemic. The mixed-media used are google forms, chat, face-to-face virtual media, hangouts, and email. Individual counselling services utilising this variety of media. These unique counselling service media serve as media for problem identification, support media for the implementation of online personal counselling services, as well as media for evaluating individual counselling services.

First, the use of chat media is always used by school counsellors with students. The use of chat media that is often applied is the WhatsApp social media application. Apart from WhatsApp, the counselling media used are Instagram and Facebook. The social media Instagram and Facebook are rarely used by school counsellors, although they also applied as counselling media. Social media in the form of chat is more effective than other media because of limitations, constraints, and problems.

The second is the use of google forms to help school counsellors. Some school counsellors use Google form in identifying student needs and problems. School counsellors only use this media on the island of Java. In addition to identification, school counsellors also use google forms to collect information related to school exams and support information related to school activities, including internet or signal difficulties. Identifying problems that are difficult to handle virtually, school counsellors carry out home visits activities while maintaining health protocols.

The third is face-to-face virtual media. School counsellors rarely use the face-toface virtual press. Counselling services are quite useful in implementing face-to-face virtual media such as zoom, Webex, Whatsapp video, and google meetings. Not all students can access face-to-face virtual counselling services. The urgency of problems that arise and can't find the solution with virtual face-to-face, the school counsellor conducts counselling at students' homes.

The fourth is email. Email as a medium in counselling services. School counsellors provide email to students. Then the students send an email in the form of a video or a letter to the school counsellor. Email is rarely applied because it has limitations in the use of counselling services. The last one is hangout as writing media in private or personal with students. This medium is also little known by school counsellors and students. Hangout as a counselling medium is limited to personal writing and creates misperceptions between school counsellors and students.

Table 2. Use of Counselling Media by School Counselors with google form in Covid-19 Epidemic

\begin{tabular}{|c|c|c|c|c|c|}
\hline No. & $\begin{array}{c}\text { Counselling } \\
\text { Media }\end{array}$ & Application & Obstacles & $\begin{array}{c}\text { Implementation } \\
\text { Objectives } \\
\text { Media } \\
\end{array}$ & $\begin{array}{l}\text { Informants } \\
\text { in research }\end{array}$ \\
\hline 1 & $\begin{array}{l}\text { Google } \\
\text { Form }\end{array}$ & $\begin{array}{l}\text { Registration media } \\
\text { in implementation } \\
\text { groups counselling } \\
\text { services or } \\
\text { individual } \\
\text { counselling } \\
\text { services. The } \\
\text { implementation is } \\
\text { by providing a } \\
\text { google form and } \\
\text { disseminating it }\end{array}$ & $\begin{array}{l}\text { Assessment } \\
\text { using with } \\
\text { google form } \\
\text { hasn't been able } \\
\text { to identify } \\
\text { student needs } \\
\text { and problems } \\
\text { comprehensively. }\end{array}$ & $\begin{array}{l}\text { Registration for } \\
\text { students had } \\
\text { problems, } \\
\text { delivery surveys, } \\
\text { and gathering } \\
\text { information. }\end{array}$ & $\begin{array}{l}\mathrm{AR}, \mathrm{II}, \mathrm{NH}, \\
\mathrm{PA} \text {, dan } \mathrm{IU}\end{array}$ \\
\hline
\end{tabular}




\begin{tabular}{|c|c|c|c|c|c|}
\hline & & $\begin{array}{l}\text { through chat } \\
\text { groups and school } \\
\text { websites. }\end{array}$ & & & \\
\hline 2 & Chat & $\begin{array}{l}\text { School counsellors } \\
\text { can read and listen } \\
\text { to students' } \\
\text { conditions and } \\
\text { feelings directly. } \\
\text { Chat between } \\
\text { school counsellors } \\
\text { and students using } \\
\text { social media such } \\
\text { as WhatsApp, } \\
\text { Facebook, } \\
\text { Instagram and } \\
\text { other social media. }\end{array}$ & $\begin{array}{l}\text { School } \\
\text { counsellors find } \\
\text { it difficult to } \\
\text { understand } \\
\text { students' } \\
\text { problems and } \\
\text { feelings. }\end{array}$ & $\begin{array}{l}\text { - Media of } \\
\text { communication } \\
\text { between school } \\
\text { counsellors and } \\
\text { students. } \\
\text { - Individual } \\
\text { counselling } \\
\text { media }\end{array}$ & $\begin{array}{l}\text { AR, SA, } \\
\text { HA, AC, IS, } \\
\text { II, NH, NT, } \\
\text { ZA, RU, } \\
\text { GU, JU, RY, } \\
\text { MRPA, BA, } \\
\text { dan IU }\end{array}$ \\
\hline 3 & $\begin{array}{l}\text { Zoom, } \\
\text { Webex, } \\
\text { WhatsApp, } \\
\text { and google } \\
\text { meeting }\end{array}$ & $\begin{array}{l}\text { Meetings of school } \\
\text { counsellors and } \\
\text { students in virtual } \\
\text { counselling, so that } \\
\text { the counselling } \\
\text { service process can } \\
\text { facilitate } \\
\text { implementation } \\
\text { with the right. }\end{array}$ & $\begin{array}{l}\text { 1. Limitations or } \\
\text { difficulties } \\
\text { with signal or } \\
\text { internet access. } \\
\text { 2. Limited or } \\
\text { uncertain } \\
\text { technology } \\
\text { tools. }\end{array}$ & $\begin{array}{l}\text { Online } \\
\text { application } \\
\text { media } \\
\text { counselling } \\
\text { services with } \\
\text { virtual face to } \\
\text { face online. }\end{array}$ & $\mathrm{NH}$ dan IU \\
\hline 4 & Hangout & $\begin{array}{l}\text { The school } \\
\text { counsellor displays } \\
\text { all connected } \\
\text { students virtually. } \\
\text { The counselling } \\
\text { service process is } \\
\text { information to } \\
\text { students with the } \\
\text { network, both } \\
\text { groups and } \\
\text { individually. }\end{array}$ & $\begin{array}{l}\text { 1. Limitations or } \\
\text { difficulties } \\
\text { with signal or } \\
\text { internet access. } \\
\text { 2. Limited or } \\
\text { insufficient } \\
\text { technological } \\
\text { tools. }\end{array}$ & $\begin{array}{l}\text { School } \\
\text { counsellors can } \\
\text { speak in writing } \\
\text { privately or } \\
\text { privately with } \\
\text { students. }\end{array}$ & IU \\
\hline 5 & Email & $\begin{array}{l}\text { The counselee } \\
\text { sends photos, } \\
\text { audio files, video, } \\
\text { and writings to the } \\
\text { school counsellor } \\
\text { email delivery as a } \\
\text { form of } \\
\text { counselling service } \\
\text { to students. }\end{array}$ & $\begin{array}{l}\text { 1. Identification } \\
\text { of needs and } \\
\text { problems isn't } \\
\text { comprehensive } \\
\text {. } \\
\text { 2.Difficulty } \\
\text { understanding } \\
\text { students' } \\
\text { conditions and } \\
\text { situations. } \\
\text { 3. Limitations or } \\
\text { issues with } \\
\text { signal or } \\
\text { internet access. } \\
\text { 4. Limited or } \\
\text { insufficient } \\
\text { technological } \\
\text { tools. }\end{array}$ & $\begin{array}{l}\text { - A means of } \\
\text { sending letters } \\
\text { through the } \\
\text { internet. } \\
\text { - Understand the } \\
\text { counselee } \\
\text { through what } \\
\text { the counselee } \\
\text { tells the } \\
\text { counsellor }\end{array}$ & II, AC, PA \\
\hline
\end{tabular}


The various media discussed have advantages and limitations. The limitations of counselling media during the Covid-19 pandemic were due to constraints in their use. Not all students have support for learning services or home counselling services. Lack of electronic devices for laptops, cellphones, and gadget is a significant obstacle. Other obstacles, such as signal and limited internet access, are urgent for students. Problems that often arise in counselling services are academic problems that affect personal, social, and career problems.

The results of the research on the constraints in counselling services with technology-based media need special attention. Restrictions Limited or difficulty in signal or internet access is the main topic in counselling services. Furthermore, the limitations or insufficiency of technological tools by students and teachers in remote areas is the main problem in learning. Besides, the identification of issues in group counselling services and individual counselling is lacking or not comprehensive, even though during the Covid-19 pandemic as the main alternative. Finally, the technology media in counselling services makes it difficult for school counsellors to understand students' problems and feelings. Feelings of sadness, joy, despair, anger, and annoyance are complicated for school counsellors to predict.

\section{Discussion}

Counselling services in Covid-19 pandemic need to be optimized because all students experience various problems. Problems that arise in students are academic, personal, social, and career. Problems that occur to students due to the unstable and new normal conditions of the Covid-19 pandemic. The new normal in the Covid-19 epidemic also didn't change the problems that occurred to students. Personal, social, academic, and career of issues experienced by students due to anxiety about the future. This condition is following the problems of other students abroad that unbearable psychological pressure and student anxiety have an effect on daily life and delay academic activities (Cao et al., 2020).

School counsellors act as individuals who are experts in assisting students through group counselling services and individual counselling. Implementation of counselling services as an act of alleviating the problems experienced by students during the Covid19 pandemic. Students being able to adapt to the conditions of the Covid-19 epidemic. Counselling services during the Covid-19 epidemic aim to reduce anxiety-online counselling service with media and technology as the main alternative. Counselling services through online media with WhatsApp, Facebook, and Instagram chat as well as virtual rooms with zoom applications, google meetings, hangouts. There is also the use of google form and email that can be used by school counsellors. School counsellors urgently need the help of technology in the era of globalization and the Covid-19 epidemic media counselling to answer the challenges and opportunities of counselling services with technology as the medium (Lattie et al., 2019).

Counsellors must understand the principles and factors in the use of digital technology as a medium for counselling services. Recommendations for counselling services in times of crisis using electronic media or social media as a medium for healing against concerns, rehabilitation efforts and post-crisis interventions (Saha et al., 2018), especially the situation against the Covid-19 pandemic. Counselling services with digital media technology as a strategy for providing counselling service assistance to students who have problems during the Covid-19 epidemic. The knowledge and skills of school counsellors in engaging social media as a media for counselling services must apply (Willow et al., 2018). The implementation of social media as a counselling medium as a 
record for school counsellors during the Covid-19 pandemic to master and utilize technology because it doesn't allow face-to-face counselling.

Individual counselling services and group counselling using social media or applications with gadget/computer/laptop via WhatsApp, Instagram, and Facebook chat. Apart from the discussion, there are also video calls with zoom, hangout, Webex, and google meeting applications. Suppose the media is limited by sending messages or email. School counsellors also implement google form as a medium for registering counselling services or recording the needs and problems experienced by students. All technology media are connected to the internet network to bring together school counsellors and students in virtual counselling so that the counselling service process can right apply. This counselling service pattern can also be called cyber counselling. The success of cyber counselling is measured client satisfaction (Zainudin \& Yusop, 2018) and technological competence can be very important for practitioners who provide longdistance counselling services (Woo et al., 2020).

Cyber counselling is a form of professionalism for school counsellors during the Covid-19 pandemic. Implementation of online counselling by school counsellors to students, school counsellors must be able to understand students. Cybercounseling services are a challenge for counsellors to strengthen and develop counselling services during the Covid-19 pandemic. Clients feel both helped and comfortable with individual counselling and the emergence of a need for virtual world counselling methods (Lan, 2016). School counsellors must optimize and master technology in the millennial era and change counselling strategies during the pandemic so that counselling services can be useful and run smoothly.

\section{Media and Technology in Counseling Services}

Media counselling during the Covid-19 pandemic used digital technology. The practice of cyber counselling services to reduce the spread of Covid-19 with school clusters and as assistance to students to alleviate the problems, they are experiencing. The use of internet-based technology to facilitate the counselling services process. Internet-of-Thins technology is communication and interactions between objects and people with smart rooms, smart parking, and the delivery of intelligent education to students (Majeed \& Ali, 2018). The development of internet users continues to increase, and the number of internet users in Indonesia is overgrowing. Social media also makes it easier for many people to communicate with other people. The application of synchronous and asynchronous interactions is a recommendation (Watts, 2016), especially in counselling services to students.

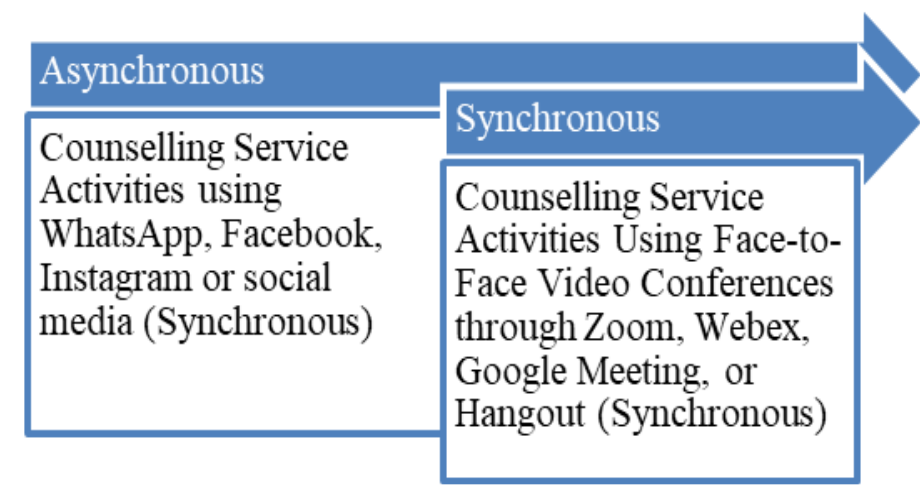

Figure 1. Synchronous and Asynchronous Media Counseling 
Applications that support the counselling process, such as personal chatting with social media (for example, WhatsApp, Facebook, Instagram or other social media) are the main choices in the Covid-19 pandemic. Meanwhile, the zoom/hangout application, email, and the use of Google Forms are alternative supporting services for counselling services. All of the applications can't from the use of the internet network. The use of chat and google forms is asynchronous media, a set of Zoom, Webex, google meeting, and hangout are synchronous media. Asynchronous media is a medium for exchanging information or dialogue or conversations between school counsellors and students through sending messages (Bourdaillet et al., 2016). Meanwhile, synchronous media is media that can synchronize the display of media objects with devices so that video and sound displays face-to-face through video conferencing, web conferences, and the virtual world in groups or individually (Bower et al., 2015; Nimrod, 2017; Shamma, 2016).

\section{Application of Counseling Services during the Covid-19 Pandemic}

The Covid-19 pandemic has a positive impact on the progress of Indonesian education in the use of technology as a period of adaptation. In general, teachers and students in Indonesia experience anxiety, pressure, and excessive fear of the slowing education process. Teachers experience high levels of stress because activities must now be limited and switched to distance learning. However, the reality is that teachers can gradually implement the use of technology. To optimize counselling services during the Covid-19 pandemic, school counsellors implemented social media in counselling services. The use of social media by considering relationships, visibility and privacy, maintains the principles of ethical counselling (Giota \& Kleftaras, 2014). The role of social media as a support for counselling services and counselling communication media following the professional ethics of the professional counsellor and the ethics of using social media (Hartley et al., 2015; Kaplan et al., 2011).

Counselling services during a pandemic can help students solve the problems they face. Counselling in the Covid-19 epidemic for students serves as an intervention to manage and handle issues effectively (Dakasku \& Musa, 2020). Assisting is intended to assist clients in dealing with all life problems that occur. Thus students can adapt to the environment. School counsellors use appropriate individual counselling techniques to change behaviour and decisions for developing the potential that is in students. Counselling service is a planned, logical, and sustainable effort to help clients develop their full potential. Besides, counselling is also to provide support for clients for their problems (Rana et al., 2020).

The conditions of the Covid-19 pandemic require school counsellors to understand student problems and ways to alleviate student problems responsively. The use of media counselling makes students more flexible in addressing their issues. School counsellors must apply confidentiality principles in the counselling process as a form of student trust. Students believe that the school counsellor will keep their problems secret, so students share personal information with school counsellors (Xiao et al., 2019). School counsellors must also create a comfortable atmosphere in the counselling process so that optimal student involvement appears in the online counselling process (Scholl et al., 2017). The involvement of school counsellors and students forms a mutually beneficial relationship. 


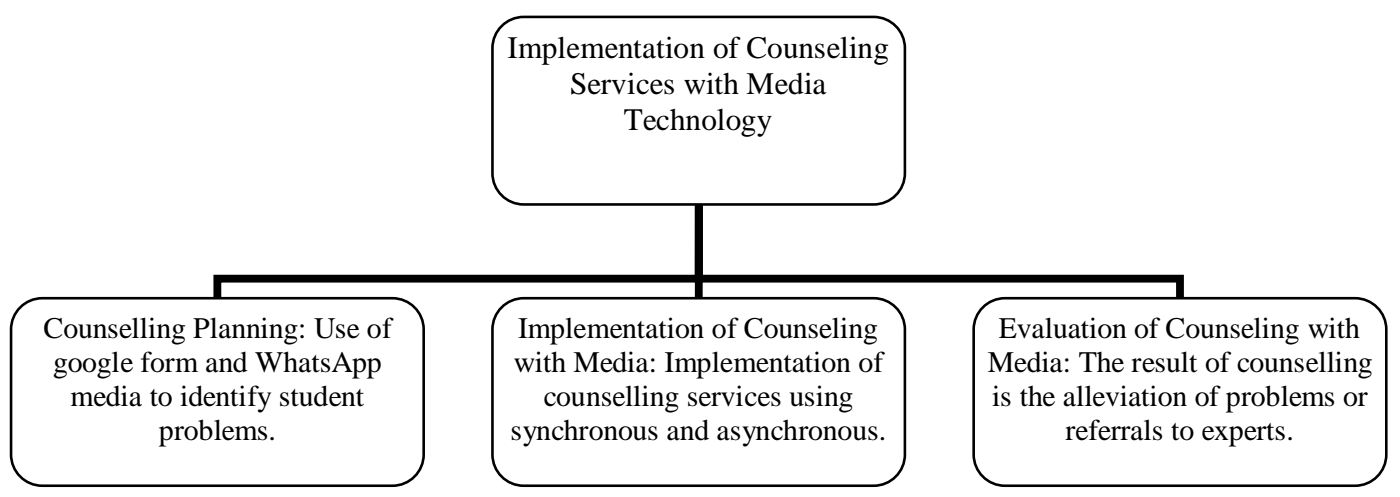

Figure 2. Implementation of Counseling Services with Media Technology

Counsellors can dig up more client information by collecting data through interviews conducted online, as well as identifying problems through asynchronous media with WhatsApp, Facebook, Instagram or social media as well as Synchronous with Zoom, Webex, Google Meetings, and Hangout media. Counselling interviews or conversations are used by counsellors to manage students' negative emotions and problem disclosure (Svinhufvud et al., 2017). In addition to interviews, counsellors can collect information and identify problems via google form and email from students to counsellors as asynchronous media. However, asynchronous media has a weakness in the lack of information obtained (Grishchenko et al., 2018). That way, the counsellor knows the right next step for the client's problem-solving process. Then give conclusions related to problem-solving in the counselling process or the needs of other experts or use the case handover method in solving situations. Transfer of cases to experts outside school counsellors must be competency-based and values-based (LloydHazlett et al., 2017). The counsellor emphasizes the application of solutions in the inference process to students.

Referrals can apply to personnel who are more skilled in handling problems, if the client needs a psychiatrist or doctor, especially in the conditions of the Covid-19 pandemic. That way, counselling services by school counsellors can be effectively used to help students as a whole, including the problems faced during the Covid-19 epidemic. Transfer of cases to doctors if it is related to student health (Aziz et al., 2020), while with mental health problems to psychologists (Chen et al., 2020). Counselling services require school counsellors to understand more deeply about client problems related to personal strengths, weaknesses and making the right decisions to solve the problem. Counselling services can apply or apply several theories in the counselling service process. The application of several counselling theories in the online counselling process is called an eclectic approach. Counselling services with an ethical approach affect reducing student anxiety or problems (Munir, 2018).

\section{Government Policy for Access to Education and Counseling Services, Teacher Professional Development}

Various obstacles related to education and counselling services are unequal internet access in different regions in Indonesia, and not all Indonesian residents use technological tools due to economic limitations. The impact is a lack of learning resources due to lack of internet access and the inability of parents to support their children's learning (Putra et al., 2020). However, the use of smartphones and personal computers with internet networks is related to individual capacity in handling problems with various information and literacy skills (Puspitasari \& Ishii, 2016). Internet access constraints in Indonesia are because Indonesia consists of multiple islands. Java Island is the centre of education, 
while the big islands in Sumatra, Kalimantan, Sulawesi, Papua, Nusa Tenggara and Bali have less than optimal internet access. There are also small islands with an education that is far from satisfactory because of the economic level compared with the city. This condition corresponding by the results of research that the use of the internet is still low due to limited internet facilities which affect students' knowledge and willingness to access the internet (Rahardjo et al., 2016). Education providers have a variety of solutions in the learning process and counselling services during the Covid-19 pandemic (Crawford et al., 2020) the new-normal era in the field of education (Prahani \& Cheng, 2020). The diversity of different solutions between schools creates gaps in educational outcomes. Various obstacles in education require policies for the development of human resources in the field of education.

The government implements policies by developing the welfare of teachers and school counsellors. One way before implementing a system is to listen to the needs of teachers in the learning process and online counselling services through various online platforms such as Zoom, or an online learning management system, and phone calls with families via WhatsApp (Collie \& Martin, 2020). Prosperity with equal internet access for students and teachers can improve the quality of learning and counselling services because most students attend the e-learning learning process with an android cellphone (Kapasia et al., 2020). In addition to internet access, the acceleration of the ability of students and teachers to face challenges in the era of disruption/ period technology 4.0/ 5.0. Increasing the capacity of students and teachers will facilitate the learning process and counselling services for students. Besides that, the availability and strategic communication of credible, non-ideological, and non-partisan knowledge can enable trust in the government (Khemani, 2020).

Availability of adequate internet access in various regions of Indonesia as an element of professional development for guidance and counselling teachers. Competent professional teachers are required to develop professional competence through continuous knowledge, attitudes and skills according to the times (D. R. F. Utami \& Latiana, 2018). Self-development in the use of technology media can be implemented through seminars and workshops, school support, and supporting facilities and infrastructure (Prawiro, 2020) for the counselling service process. Technology mediabased counselling services in the disruption era or the technology era 4.0/5.0 require mentoring, professional teachers, school managerial, and online learning or service facilities (I. L. P. Utami, 2018). The use of technology media can increase student interest in the implementation of counselling services in schools (Alhadi et al., 2016).

\section{CONCLUSION}

School counsellors during the Covid-19 pandemic had challenges in implementing online counselling with individual counseling services and group counseling services. The implementation of counseling services for students by school counsellors uses technology media as an element of developing the professional competence of school counsellors. Professional guidance and counseling teachers can plan, implement, and evaluate themselves in the use of technology media in counseling services. The technology media used are synchronous and asynchronous based. Asynchronous media with WhatsApp, Facebook, Instagram or social media. Sync with Media Zoom, Webex, Google Meetings and Hangouts. It is identification information related to student problems using WhatsApp or Google Form. While the implementation of counselling through technology media is used based on synchronous and asynchronous according to student needs. The use of counseling media can make students more flexible in conveying their problems with the principle of confidentiality in the process of online counseling 
services or cyber-counselling. Application of online counseling services or cyber counseling to help student problem solving and for students who experience issues beyond the competence of the counsellor, the counsellor will transfer the case to a more competent party. The role of the government through policies in education helps provide internet access and the development of literacy skills for students and teachers.

\section{ACKNOWLEDGMENTS}

Thanks to alumni of teacher professional education programs by field of study guidance and counselling or school counsellor. All alumni have provided valid and reliable data for scientific development on online counselling during the Covid-19 pandemic. Thanks to Teacher Professional Education Study Program, Study Program Guidance and Counseling in Universitas Ahmad Dahlan, and Study Program Guidance and Counseling in Pancasakti Tegal Univercity permission for data retrieval to twenty alumni. Acknowledgements expressed as a form of appreciation for the facts and efforts to develop guidance and counselling science in Indonesia.

\section{REFERENCE}

Abdullah, I. (2020). COVID-19: Threat and fear in Indonesia. Psychological Trauma: Theory, Research, Practice, and Policy, 12(5), 488.

Alhadi, S., Supriyanto, A., \& Dina, D. A. M. (2016). Media in guidance and counseling services: A tool and innovation for school counselor. SCHOULID: Indonesian Journal of School Counseling, 1(1), 6-11.

Aliyyah, R. R., Rachmadtullah, R., Samsudin, A., Syaodih, E., Nurtanto, M., \& Tambunan, A. R. S. (2020). The Perceptions of Primary School Teachers of Online Learning during the COVID-19 Pandemic Period: A Case Study in Indonesia. Journal of Ethnic and Cultural Studies, 7(2), 90-109.

Almanthari, A., Maulina, S., \& Bruce, S. (2020). Secondary School Mathematics Teachers' Views on E-learning Implementation Barriers during the COVID-19 Pandemic: The Case of Indonesia. Eurasia Journal of Mathematics, Science and Technology Education, 16(7), em1860.

Aziz, A., Zork, N., Aubey, J. J., Baptiste, C. D., D’alton, M. E., Emeruwa, U. N., Fuchs, K. M., Goffman, D., Gyamfi-Bannerman, C., \& Haythe, J. H. (2020). Telehealth for high-risk pregnancies in the setting of the COVID-19 pandemic. American Journal of Perinatology, 37(8), 800.

Bourdaillet, J. J. L., Peng, W., Sun, T., \& Szymanski, M. H. (2016). Conversation analysis of asynchronous decentralized media. Google Patents.

Bower, M., Dalgarno, B., Kennedy, G. E., Lee, M. J., \& Kenney, J. (2015). Design and implementation factors in blended synchronous learning environments: Outcomes from a cross-case analysis. Computers \& Education, 86, 1-17.

Brown, N., Te Riele, K., Shelley, B., \& Woodroffe, J. (2020). Learning at home during COVID-19: Effects on vulnerable young Australians. Independent Rapid Response Report.

Burgess, S., \& Sievertsen, H. H. (2020). Schools, skills, and learning: The impact of COVID-19 on education. VoxEu. Org, 1 .

Cao, W., Fang, Z., Hou, G., Han, M., Xu, X., Dong, J., \& Zheng, J. (2020). The psychological impact of the COVID-19 epidemic on college students in China. Psychiatry Research, 112934.

Chen, S., Li, F., Lin, C., Han, Y., Nie, X., Portnoy, R. N., \& Qiao, Z. (2020). Challenges and recommendations for mental health providers during the COVID-19 
pandemic: The experience of China's First University-based mental health team. Globalization and Health, 16(1), 1-10.

Collie, R., \& Martin, A. (2020). Teacher wellbeing during COVID-19.

Crawford, J., Butler-Henderson, K., Rudolph, J., Malkawi, B., Glowatz, M., Burton, R., Magni, P., \& Lam, S. (2020). COVID-19: 20 countries' higher education intraperiod digital pedagogy responses. Journal of Applied Learning \& Teaching, 3(1), $1-20$.

Cucinotta, D., \& Vanelli, M. (2020). WHO declares COVID-19 a pandemic. Acta BioMedica: Atenei Parmensis, 91(1), 157-160.

Dakasku, U. M., \& Musa, S. (2020). Counselling As A Panacea For Stress Management During Covid-19 Pandemic Lockdown.

Djalante, R., Lassa, J., Setiamarga, D., Mahfud, C., Sudjatma, A., Indrawan, M., Haryanto, B., Sinapoy, M. S., Rafliana, I., \& Djalante, S. (2020). Review and analysis of current responses to COVID-19 in Indonesia: Period of January to March 2020. Progress in Disaster Science, 100091.

Giota, K. G., \& Kleftaras, G. (2014). Social media and counseling: Opportunities, risks and ethical considerations. International Journal of Psychological and Behavioral Sciences, 8(8), 2386-2388.

Greenhalgh, T., Wherton, J., Shaw, S., \& Morrison, C. (2020). Video consultations for covid-19. British Medical Journal Publishing Group.

Grishchenko, D., Iutzeler, F., Malick, J., \& Amini, M.-R. (2018). Asynchronous distributed learning with sparse communications and identification. ArXiv Preprint ArXiv:1812.03871.

Hartley, M. T., Johnston, S. P., \& Tarvydas, V. M. (2015). The ethics and practice of social media advocacy in rehabilitation counseling. Journal of Rehabilitation, 81(1), 42.

Ifdil, I., Fadli, R. P., Suranata, K., Zola, N., \& Ardi, Z. (2020). Online mental health services in Indonesia during the COVID-19 outbreak. Asian Journal of Psychiatry.

Iyer, P., Aziz, K., \& Ojcius, D. M. (2020). Impact of COVID-19 on dental education in the United States. Journal of Dental Education, 84(6), 718-722.

Kapasia, N., Paul, P., Roy, A., Saha, J., Zaveri, A., Mallick, R., Barman, B., Das, P., \& Chouhan, P. (2020). Impact of lockdown on learning status of undergraduate and postgraduate students during COVID-19 pandemic in West Bengal, India. Children and Youth Services Review, 116, 105194.

Kaplan, D. M., Wade, M. E., Conteh, J. A., \& Martz, E. T. (2011). Legal and ethical issues surrounding the use of social media in counseling. Counseling and Human Development, 43(8), 1.

Khemani, S. (2020). An Opportunity to Build Legitimacy and Trust in Public Institutions in the Time of COVID-19. World Bank.

Lan, C.-M. (2016). Predictors of willingness to use cyber counseling for college students with disabilities. Disability and Health Journal, 9(2), 346-352.

Lattie, E. G., Lipson, S. K., \& Eisenberg, D. (2019). Technology and college student mental health: Challenges and opportunities. Frontiers in Psychiatry, 10, 246.

Lloyd-Hazlett, J., Hobbs, J. R., \& Honderich, E. M. (2017). Student counselors' perceptions of ethical client referrals. Counseling and Values, 62(2), 180-197.

Majeed, A., \& Ali, M. (2018). How Internet-of-Things (IoT) making the university campuses smart? QA higher education (QAHE) perspective. 2018 IEEE 8th Annual Computing and Communication Workshop and Conference (CCWC), 646-648. 
Munir, A. (2018). The Effect Of Group Counselling Services Using An Eclectic Approach To Anxiety Talking In Front Of The Class Students At SMA Negeri 4 Medan, 2017/2018. IOSR Journal of Humanities and Social Science (IOSR-JHSS), 23(7), 7.

Nimrod, G. (2017). Older audiences in the digital media environment. Information, Communication \& Society, 20(2), 233-249.

Pragholapati, A. (2020). COVID-19 IMPACT ON STUDENTS.

Prahani, B. K., \& Cheng, T.-H. (2020). "New Normal" in Learning and Teaching. Studies in Learning and Teaching, 1(2), 63-65.

Prawiro, I. Y. (2020). Vocational Teachers Challenges in Developing Their Professional Competence in Indramayu. Vision: Journal for Language and Foreign Language Learning, 8(2), 169-180.

Purwanto, A., Asbari, M., Fahlevi, M., Mufid, A., Agistiawati, E., Cahyono, Y., \& Suryani, P. (2020). Impact of Work From Home (WFH) on Indonesian Teachers Performance During the Covid-19 Pandemic: An Exploratory Study. International Journal of Advanced Science and Technology, 29(05), 6235-6244.

Puspitasari, L., \& Ishii, K. (2016). Digital divides and mobile Internet in Indonesia: Impact of smartphones. Telematics and Informatics, 33(2), 472-483.

Putra, P., Liriwati, F. Y., Tahrim, T., Syafrudin, S., \& Aslan, A. (2020). The Students Learning from Home Experiences during Covid-19 School Closures Policy In Indonesia. Jurnal Iqra': Kajian Ilmu Pendidikan, 5(2), 30-42.

Rahardjo, D., Lubis, D. P., \& HARIJATI, I. S. (2016). Internet Access And Usage In Improving Students'self-Directed Learning In Indonesia Open University. Turkish Online Journal of Distance Education, 17(2).

Rana, W., Mukhtar, S., \& Mukhtar, S. (2020). Mental health of medical workers in Pakistan during the pandemic COVID-19 outbreak. Asian Journal of Psychiatry, $51,102080$.

Saha, K., Weber, I., \& De Choudhury, M. (2018). A social media based examination of the effects of counseling recommendations after student deaths on college campuses. Proceedings of the... International AAAI Conference on Weblogs and Social Media. International AAAI Conference on Weblogs and Social Media, 2018, 320 .

Scholl, M. B., Hayden, S. C., \& Clarke, P. B. (2017). Promoting optimal student engagement in online counseling courses. The Journal of Humanistic Counseling, 56(3), 197-210.

Setiati, S., \& Azwar, M. K. (2020). COVID-19 and Indonesia. Acta Medica Indonesiana, 52(1), 84-89.

Shamma, D. A. (2016). Synchronous delivery of media content in a collaborative environment. Google Patents.

Svinhufvud, K., Voutilainen, L., \& Weiste, E. (2017). Normalizing in student counseling: Counselors' responses to students' problem descriptions. Discourse Studies, 19(2), 196-215.

Utami, D. R. F., \& Latiana, L. (2018). Teachers' Perception of The Professional Competencies and Digital Media Use at Early Childhood Institution in Indonesia. 4th International Conference on Early Childhood Education. Semarang Early Childhood Research and Education Talks (SECRET 2018).

Utami, I. L. P. (2018). The Online Learning of Teacher Profession Education Program (PPG) for In-Service English Teachers: Challenges and Accelerated Learning Factors. JPI (Jurnal Pendidikan Indonesia), 7(2), 145-153. 
Van Bavel, J. J., Baicker, K., Boggio, P. S., Capraro, V., Cichocka, A., Cikara, M., Crockett, M. J., Crum, A. J., Douglas, K. M., \& Druckman, J. N. (2020). Using social and behavioural science to support COVID-19 pandemic response. Nature Human Behaviour, 1-12.

Vostanis, P., \& Bell, C. A. (2020). Counselling and psychotherapy post-COVID-19. Counselling and Psychotherapy Research, 20(3), 389-393.

Watts, L. (2016). Synchronous and asynchronous communication in distance learning: A review of the literature. Quarterly Review of Distance Education, 17(1), 23.

Willow, R. A., Tobin, D., Chong, W. Y., Jeffery, A., Strohmeyer, D., \& Morine, N. (2018). A social media policy for clinical mental health counseling programs. The Journal of Counselor Preparation and Supervision, 11(2), 9.

Woo, H., Dondanville, A., Jang, H., Na, G., \& Jang, Y. (2020). A Content Analysis of the Counseling Literature on Technology Integration: American Counseling Association (ACA) Counseling Journals between 2000 and 2018. International Journal for the Advancement of Counselling, 42(3), 319-333.

Xiao, Z., Rodriguez, M. A., Fang, C. M., Gao, J., Robins, C., \& Rosenthal, M. Z. (2019). The effect of patient education on Chinese adolescent and parental beliefs about counselors' breaches of confidentiality. The Journal of Behavioral Health Services \& Research, 46(2), 340-352.

Yanti, B., Wahyudi, E., Wahiduddin, W., Novika, R. G. H., Arina, Y. M. D., Martani, N. S., \& Nawan, N. (2020). Community knowledge, attitudes, and behavior towards social distancing policy as prevention transmission of COVID-19 in indonesia. Jurnal Administrasi Kesehatan Indonesia, 8(2), 4-14.

Zainudin, Z. N., \& Yusop, Y. M. (2018). Client's Satisfaction in Face-to Face Counseling and Cyber Counseling Approaches: A Comparison. International Journal of Academic Research in Business and Social Sciences, 8(3), 677-684.

Zhang, W., Wang, Y., Yang, L., \& Wang, C. (2020). Suspending classes without stopping learning: China's education emergency management policy in the COVID-19 Outbreak. Multidisciplinary Digital Publishing Institute. 